\title{
A standard clot method for the assay of plasminogen activators, anti-activators, and plasmin
}

\author{
CHRISTINE M. HAWKEY AND J. L. STAFFORD \\ From the Haematology Department, St. George's Hospital Medical School, London
}

SYNOPSIS. Details are given of the selection and standardization of reagents for use in a standard clot method for estimating plasminogen activators, anti-activators, and plasmin.

Substrate standardization is necessary for the assay of components of the fibrinolytic system, not only to permit reproducibility in the laboratory but, in particular, to facilitate comparison of results recorded in different centres during the development of this relatively new subject. Difficulties experienced with reproducibility are due mainly to the fact that commercially available fibrinogens and thrombins are contaminated in varying degree by other components of the fibrinolytic system, whilst human plasminogen is difficult and expensive to prepare. Procedures involving a standard clot have already been used (Christensen, 1949; Johnson and Tillett, 1952; Fletcher, 1954; Baumgarten, Ciminera, and Cole, 1960). The purpose of this communication is the detailed description of a method found to be suitable for general laboratory use, incorporating reagents readily available in Europe: the results obtained during standardization are recorded and the selected commercial preparations specified.

The standard clot comprises fibrinogen and thrombin, to which plasminogen and activator may be added if appropriate. It is made up to a fixed volume with buffer and thus provides 'reagent' space so that the components to be tested are actually included in the fibrin clot and their intrinsic effect on the subsequent lysis time can be measured. The method depends on the fibrin clot so formed being reproducible, stable, of constant volume, and uniformly susceptible to the action of plasmin. It offers a number of advantages over others in current use. The selection of fibrin as the substrate more nearly reproduces physiological conditions than does that of casein or the synthetic esters. It is shorter and easier to use quantitatively than the fibrin plate method (Astrup and Mullertz, 1952) which has the further disadvantage that the test substance cannot actually be incorporated in the

Received for publication 26 September 1963. clot. Neither the special apparatus required for the ${ }^{131}$ I-labelled clot procedure nor the preparations involved in the standard thrombus (Blix, 1962) are necessary.

\section{METHOD}

Only those materials easily obtainable in Europe or prepared in the laboratory have been investigated and, when possible, more than one batch of each reagent has been tested to assess variation from batch to batch. Throughout, meticulous attention has been paid to storage and the provision of optimal conditions necessary for the maintenance of stability.

Other workers have already selected $1.1 \mathrm{ml}$. as a standard volume and this provides a conveniently sized test system. Basically, the clot consists of $0.2 \mathrm{ml}$. fibrinogen and $0.1 \mathrm{ml}$. thrombin, each in a pre-standardized solution, leaving a reagent space of $0.8 \mathrm{ml}$. into which plasminogen, activator, and test substances can be introduced as desired, the volume being made up by saline phosphate buffer (Appendix 1).

The test is carried out in new $75 \times 12 \mathrm{~mm}$. glass testtubes which have been washed in detergent, rinsed, soaked overnight in $2 \% \mathrm{HCl}$, and re-rinsed thoroughly with tap and then distilled water. Tubes and reagents are placed in an ice-bath. Reagents are added as rapidly as possible in the sequence saline buffer, plasminogen, fibrinogen, activator, and, finally, thrombin; several tubes can be set up together, providing that the total length of time spent in preparation is not more than one and a half minutes. A stop-watch is started as the thrombin is added, the contents of the tube are quickly mixed, preferably by means of an automatic mixer, and the tubes transferred to a water-bath at $37^{\circ} \mathrm{C}$. One minute later they are examined to confirm that clotting has taken place; thereafter they are examined every 30 seconds, or at regular intervals determined by experience of the particular test being carried out. The end-point is taken as the time of complete disappearance of the clot and is recorded as the lysis time in minutes.

INTERPRETATION OF RESULTS The lysis times of serial dilutions of the test substances are plotted against 
concentration. A 'standard clot' unit of activity is the concentration required to produce complete lysis in an arbitrarily fixed time. It is convenient to select 10 minutes for this purpose.

\section{REAGENTS}

Two points in the selection of reagents merit emphasis. With all protein substrates, the varying amount of contamination must be assessed and, if possible, the cause identified (Appendix 2). The choice of buffer can be critical: either as a result of interaction with the different proteins or because of its effect upon ionic calcium, the solution used can exert an influence on results. Calcium inhibits some phases of the fibrinolytic mechanism (Bruce, 1964) and so a saline phosphate buffer ( $p \mathrm{H} \mathrm{7 \cdot 5)}$ has been used in the tests described in this paper because ionic calcium is removed as calcium phosphate. The inclusion of a trace of merthiolate in the buffer has not been found to influence the results of the test, and is useful in preventing the growth of contaminating moulds and algae. In the preparation of streptokinase dilutions, gelatin is added to the buffer solution because the provision of a gel serves to stabilize the streptokinase during the time taken to complete the procedures (Appendix 3).

FIBRINOGEN It is, of course, preferable to use human fibrinogen as a substrate and that manufactured by $\mathrm{Kabi}$ (Sweden) is to be recommended. But this is relatively expensive and, as fibrinogen is a basic component of the standard clot, it is important to have a source from which it can be obtained readily and cheaply. For this reason Armour bovine plasma fraction I has been selected, although it is known to contain severa官 batch to batch, and a substantial proportion of the dry powder is citrate.

The freeze-dried fraction $I$ is stored at $4^{\circ} \mathrm{C}$. and weighed out as required. It is dissolved in saline phosphate buffer at $37^{\circ} \mathrm{C}$. for 15 minutes and then kept in an icebath where it remains stable for at least four hours. If precipitate forms at this temperature ('profibrin') it can be re-dissolved by warming the solution to $37^{\circ} \mathrm{C}$. for a few minutes.

Three batches have been tested: each was found to contain differing amounts of clottable protein, plasminogen activator, plasminogen itself, and inhibitors (Table I) The trace of plasminogen activator detectable on the fibrin plate was not enough to cause lysis of a standard $\vec{V}$ clot in 24 hours and was, therefore, not considerediv relevant. The unpredictable effect of the plasminogen could be eliminated by the deliberate addition of excess $\mathrm{F}$ plasminogen from human serum euglobulin (see later). 으 Even though the effect of plasminogen contaminationwas nullified in this way, variation of the clot lysis time 3 still occurred when $1 \%$ solutions $(w / v)$ of different batches of fraction I were used in the preparation of streptokinase-activated standard clots. Moreover, this $\overrightarrow{0}$ could not be corrected by separating out contaminanto antiplasmins by euglobulin precipitation. Calibration curves for streptokinase made with fraction I from the various batches were, however, always found to bes parallel when the plasminogen level was controlled (Fig. 1); from this observation it was concluded that theo concentration of substrate was itself influencing the result, and estimation of clottable protein in each batch confirmed that this varied. By adjusting the amountō

TABLE I

RESULTS OF TESTS FOR CONTAMINANTS IN REAGENTS

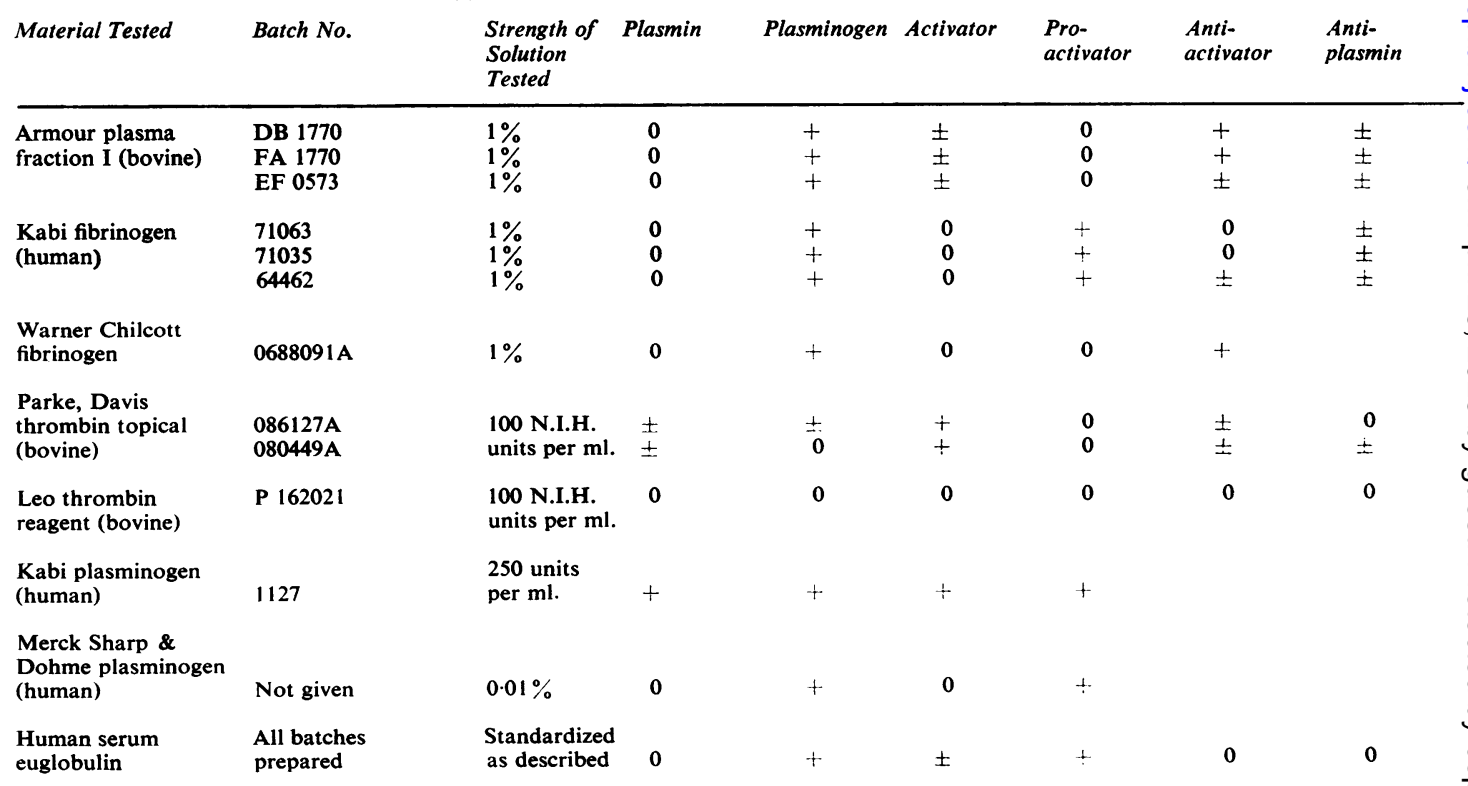




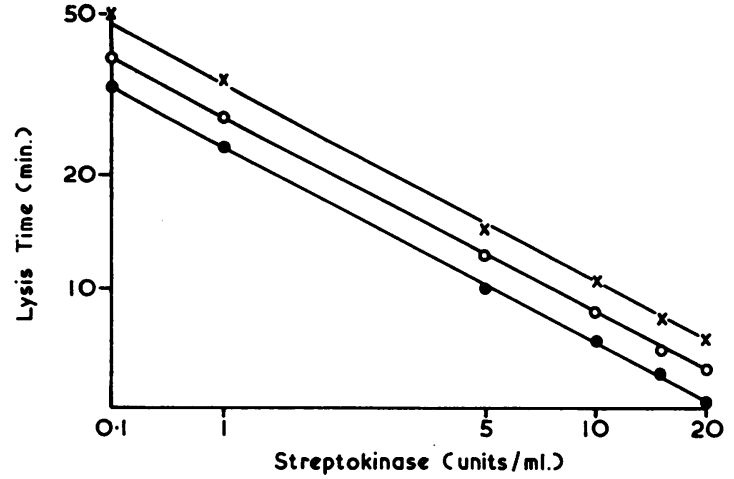

FIG. 1. Streptokinase dilution curves using $1 \%$ solutions of different batches of fraction $I$.

- EF 0573, O-O FA 1770, ×——DB 1770. The streptokinase units referred to are manufacturer's units.

$(w / v)$ of fraction $I$ in the standard clot and thus controlling the ultimate amount of fibrin formed, it was found that unknown batches of fraction I could be standardized against a pre-selected control batch.

Standardization Initially a streptokinase dilution curve was plotted for each of the three fibrinogen batches examined, using a standard clot mixture incorporating $1 \%$ fibrinogen solution (Fig. 1). The batch providing the fastest lysis time (Armour EF 0573) was selected and, thereafter, $0.2 \mathrm{ml}$. of a $1 \%$ solution of this batch $(50 \mathrm{mg}$. in $5 \mathrm{ml}$. saline phosphate buffer) was used in the preparation of every standard clot.

Although batch EF 0573 fibrinogen was established as the reference for all subsequent estimations, the concentration of other batches of fraction I was determined which would provide similar results. Standard clots incorporating serial dilutions of the unknown fraction I were prepared in parallel with the reference fibrinogen. For this particular experiment, streptokinase in a concentration of $10 \mathrm{units} / \mathrm{ml}$, providing a 10-minute lysis time, was diluted to $1 \mathrm{unit} / \mathrm{ml}$., thus prolonging the time of complete lysis to 20 to 23 minutes (Table II).

\section{TABLE II}

STANDARDIZATION OF FIBRINOGEN (ARMOUR BOVINE PLASMA FRACTION I)

Fraction I Lysis Time in Minutes

Batch No.

\begin{tabular}{lllllll} 
& \multicolumn{6}{c}{ Volume of $1 \%$ Fraction I Solution in Standard Clot } \\
\cline { 2 - 7 } & 0.3 & $0 \cdot 25$ & $0 \cdot 2$ & $0 \cdot 15$ & $0 \cdot 1$ & 0.05 \\
\hline EF 0573 & & & 22 & & & \\
FA 1770 & 82 & 52 & 45 & $28 \frac{1}{2}$ & 22 & 13 \\
DB 1770 & 36 & 33 & 25 & 21 & 16 & 12
\end{tabular}

The amount of fraction $I$ in the clot which lysed at the same speed as that containing reference fibrinogen was then calculated: using a solution containing this quantity in $\mathbf{0 . 2} \mathrm{ml}$., the calibration curve for streptokinase was found to coincide exactly with the curve from the
TABLE III

STREPTOKINASE DILUTION CURVES WITH STANDARDIZED FIBRINOGEN (ARMOUR BOVINE PLASMA FRACTION I)

\begin{tabular}{lllllll}
$\begin{array}{l}\text { Fraction I } \\
\text { Batch No. }\end{array}$ & \multicolumn{5}{l}{ Lysis Time in Minutes } \\
\cline { 2 - 7 } & \multicolumn{5}{l}{ Streptokinase (units/ml.) } \\
\cline { 2 - 7 } & 20 & 15 & 10 & 5 & 1 & 0.5 \\
\hline EF 0573 & $5 \frac{1}{2}$ & 6 & $7 \frac{1}{2}$ & 9 & $21 \frac{1}{2}$ & $39 \frac{1}{2}$ \\
FA 1770 & 5 & 6 & $6 \frac{1}{2}$ & $8 \frac{1}{2}$ & $21 \frac{39}{2}$ \\
DB 1770 & $4 \frac{1}{2}$ & 6 & 7 & 9 & $21 \frac{1}{2}$ & 38
\end{tabular}

$10.1 \mathrm{ml}$. of solution is added to each standard clot.

reference batch within the range 50 to 0.5 units streptokinase per millilitre.

The standardization of Armour batches FA 1770 and DB 1770 (Tables II and III) showed that these could be used in the preparation of a standard clot as follows:-

FA 1770: $0.2 \mathrm{ml}$. of a solution containing $37.5 \mathrm{mg}$. in $5 \mathrm{ml}$. SP buffer $(0.75 \% \mathrm{w} / \mathrm{v})$.

DB 1770: $0.2 \mathrm{ml}$. of a solution containing $25 \mathrm{mg}$. in $5 \mathrm{ml}$. SP buffer $(0.5 \% \mathrm{w} / \mathrm{v})$.

Other sources Warner bovine fibrinogen has been found to be free from significant contamination with activator although the batch tested contained some plasminogen (Table I). Batches of Kabi human fibrinogen, which should be standardized as described for use in the standard clot, have also been found to be free from activator and, if necessary, the plasminogen can be removed by the method of Mosesson (1962).

Howell (1963) refers to the use of time-expired bank blood as a convenient laboratory source of human fibrinogen which can be used when plasminogen contamination does not matter: a plasma-euglobulin preparation gives a fibrinogen-plasminogen mixture free from anti-plasmin activity.

THROMBIN Two commercial thrombin preparations, both of bovine origin, were assessed: Thrombin Topical (Parke, Davis) and Thrombin Reagent (Leo Laboratories). A thrombin/fibrinogen curve, prepared for each batch, showed the thrombins to be equal in their power to clot fibrinogen. The results of tests for contamination with components of the fibrinolytic system are given in Table $I$. These show that each of the two batches of Thrombin Topical tested contained contaminants likely to influence the results of tests of fibrinolytic activity; this has also been found by other workers (McNicol, 1962; Innes, 1962). Only one batch of Thrombin Reagent was available: this was found to be remarkably free from contaminants and this fact, together with an assurance from the manufacturers that this batch will be used as a reference standard for all future batches, leads us to recommend the Leo preparation for use in the standard clot.

Thrombin can be stored for up to two months at $-35^{\circ} \mathrm{C}$. in measured aliquots of a solution containing 500 N.I.H. units/ml. saline in plastic containers. For use it is diluted 1:10 with saline phosphate buffer; this solution will remain active for eight hours in an ice-bath.

It is important to use enough thrombin to convert all the fibrinogen present in the system rapidly to fibrin. If conversion is incomplete or if there is time for significant 
fibrinogenolysis to occur, the final amount of fibrin substrate in the test will be reduced. By using uncontaminated thrombin it is permissible to add an excess to the standard clot system, thus ensuring complete and rapid fibrin formation. Thrombin Reagent is best used in a concentration of 50 N.I.H. units $/ \mathrm{ml}$. and $0.1 \mathrm{ml}$. of this solution will bring about clotting in a $1.1 \mathrm{ml}$. standard clot in less than 30 seconds.

PLASMINOGEN Although it is stable in blood, pure plasminogen is difficult and expensive to prepare and is unstable. It is present in Cohn plasma fraction III but, unfortunately, human fraction III is not readily available in Great Britain. Of the commercial preparations tested, Kabi human plasminogen was found to be partially activated to plasmin. The purity of the Merck Sharp \& Dohme preparation would make it ideal for use in the standard clot but it is very unstable in solution and must be kept on ice: it is best used as $0.1 \mathrm{ml}$. of a solution containing $1 \mathrm{mg}$. plasminogen $/ \mathrm{ml}$. saline phosphate buffer. Using a concentrated solution the marked instability can be ignored for the period of the experiment.

Human serum euglobulin, prepared from pooled plasma taken from time-expired banked acid-citratedextrose blood, is a satisfactory source of plasminogen available in all clinical laboratories (Appendix 4). Serum, rather than plasma, is used to preclude inaccuracy due to the presence of further fibrinogen altering the final concentration of substrate: antiplasmins remain in the supernatant during euglobulin precipitation and can be rejected, and although anti-activators formed during the collection of blood (Flute, 1960) are precipitated with the euglobulin, their effect can be diluted out. Some activator activity persists (Table I) but this is insufficient to lyse a standard clot in 12 hours and can thus be regarded as insignificant. Aliquots of the euglobulin, re-dissolved in saline phosphate buffer, can be stored at $-35^{\circ} \mathrm{C}$. in plastic containers: full activity is retained for at least three months.

Standardization of human serum euglobulin Serial dilutions of stock euglobulin solution are incorporated in the standard clot as follows:-

Euglobulin + buffer.......... $0 \cdot 7$

Fibrinogen ................ $0 \cdot 2$

Streptokinase ....................

Thrombin $\ldots \ldots \ldots \ldots \ldots \ldots \ldots .1$

(For details of reagents see Appendix 1.)

Typical lysis results are given in Table IV: the dilution producing the shortest lysis time is selected for use. A solution calculated to contain the required amount of plasminogen in $0.1 \mathrm{ml}$. is prepared by dilution of the stored stock solution. Unlike purified plasminogen, this solution will remain stable for eight hours in an ice-bath and shows no tendency towards autoactivation.

PLASMINOGEN ACTIVATORS The activators of plasmino gen most generally used in laboratory estimations ared streptokinase and urokinase. At present streptokinase is the cheaper and more readily available.

Streptokinase Several commercial preparations are available, each of which is suitable for use in the standard clot, provided that standardization is carried out. In the $\overrightarrow{c t}$ present study Varidase (Lederle) has been used: this is most satisfactory as long as precautions are taken tof prevent deterioration of prepared solutions.

Varidase is supplied as freeze-dried material in vials containing 100,000 manufacturer's units. For the preparation of a stock solution $10 \mathrm{ml}$. of ice-cold norma saline is added to the vial giving a solution containing 10,000 units per $\mathrm{ml}$. After mixing, the streptokinase solution is distributed in measured aliquots into plastic tubes which are immediately frozen at $-35^{\circ} \mathrm{C}$. One tube is retained for standardization which is carried out as soon as possible. Each vial must be standardized, but the stock solution frozen at $-35^{\circ} \mathrm{C}$. has been found too retain its full activity for at least one month.

Standardization All dilutions are made in gel buffer

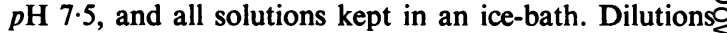
are prepared as follows:-

\begin{tabular}{ccc}
$\begin{array}{l}\text { Streptokinase }(100 \\
\text { manufacturer's units/ml.) }\end{array}$ & $\begin{array}{l}\text { Gel Buffer } \\
(\mathrm{ml} .)\end{array}$ & $\begin{array}{l}\text { Final Strength of } \\
\text { Streptokinase } \\
\text { (manufacturer's units/ml.) }\end{array}$ \\
\hline 1.0 & 4.0 & 20 \\
0.75 & 4.25 & 15 \\
0.5 & 4.5 & 10 \\
0.25 & 4.75 & 5 \\
0.05 & 4.95 & 1
\end{tabular}

Each dilution is tested in the following standard clop mixture:

Saline phosphate buffer $\ldots \ldots \ldots 0.6$

Euglobulin ............... 0.1

Fibrinogen ............... $0 \cdot 2\} 1.1 \mathrm{ml}$.

Streptokinase dilution $\ldots \ldots \ldots \ldots 0 \cdot 1$

Thrombin ................

(For details of reagents see Appendix 1.)

The lysis time in minutes is plotted against the con centration of streptokinase on double logarithmic graplos paper. This will give a straight line. The dilution giving a lysis time of $10 \mathrm{~min}$. is read from the graph; b)

TABLE IV

STANDARDIZATION OF PLASMINOGEN (HUMAN SERUM EUGLOBULIN)

\begin{tabular}{|c|c|c|c|c|c|}
\hline $\begin{array}{l}\text { Saline Phosphate Buffer } \\
\text { ( } \mathrm{ml} . \text { ) }\end{array}$ & $\begin{array}{l}\text { Serum Euglobulin } \\
(\mathrm{ml} .)\end{array}$ & $\begin{array}{l}\text { Streptokinase } \\
(10 \text { units } / \mathrm{ml} .)(\mathrm{ml} .)\end{array}$ & $\begin{array}{l}\text { Standard } \\
\text { Fibrinogen }(m l .)\end{array}$ & $\begin{array}{l}\text { Standard Thrombin } \\
(m l .)\end{array}$ & Lysis Time (min.) \\
\hline $\begin{array}{l}0 \\
0 \cdot 2 \\
0.4 \\
0 \cdot 5 \\
0 \cdot 6 \\
0 \cdot 65 \\
0.675 \\
0.7\end{array}$ & $\begin{array}{l}0.7 \\
0.5 \\
0.3 \\
0.2 \\
0.1 \\
0.05 \\
0.025 \\
0\end{array}$ & $\begin{array}{l}0 \cdot 1 \\
0 \cdot 1 \\
0 \cdot 1 \\
0 \cdot 1 \\
0 \cdot 1 \\
0 \cdot 1 \\
0 \cdot 1 \\
0 \cdot 1\end{array}$ & $\begin{array}{l}0.2 \\
0.2 \\
0.2 \\
0.2 \\
0.2 \\
0.2 \\
0.2 \\
0.2\end{array}$ & $\begin{array}{l}0 \cdot 1 \\
0 \cdot 1 \\
0 \cdot 1 \\
0 \cdot 1 \\
0 \cdot 1 \\
0 \cdot 1 \\
0 \cdot 1 \\
0 \cdot 1\end{array}$ & $\begin{array}{c}17 \\
14 \\
12 \\
11 \\
10 \frac{1}{2} \\
11 \\
11 \\
>12 \text { hours }\end{array}$ \\
\hline
\end{tabular}


definition this will contain 1 'standard clot' unit of streptokinase in $0.1 \mathrm{ml}$. (to be distinguished from the manufacturer's unit). This dilution is then prepared for use from the stock solution.

It is particularly important that dilutions should be made in gel buffer and kept at all times in an ice-bath. If these conditions are strictly observed the solutions will remain stable for up to four hours.

Urokinase This is a suitable activator for use in all tests except those where proactivator is to be estimated. It is obtainable from Leo Pharmaceutical Products in ampoules containing 25,000 Ploug units. Standardization may be carried out as for streptokinase, and each new vial must be standardized. The material is more stable than streptokinase and solutions kept in an icebath retain full activity for eight hours. Stock solutions containing 10,000 units per ml. of saline should be stored at $-35^{\circ} \mathrm{C}$.

\section{APPLICATIONS OF STANDARD CLOT METHOD}

The purpose of the standard clot method is not to supplant biochemical standardization, which is necessarily a highly technical commitment, but to augment the facilities of the average clinical laboratory. Its principal virtue is the ease with which the basic method can be adapted to measure the activity of plasmin, antiplasmin, activator, or anti-activator (the latter including the antagonistic effect of antistreptococcal antibodies). It is also possible to measure plasminogen concentration but as this involves the use of a different fibrinogen preparation it will be reported elsewhere.

ACTIVATOR ACTIVITY ASSAY The method is not suitable for the measurement of intrinsic plasma activator because for this it is necessary to remove all naturally occurring inhibitors from the test plasma. It is, however, very useful for estimating the activity of artificial activators; this is carried out as described for the standardization of streptokinase. The method can also be used for assessing the activity of tissue activator which does not normally occur in association with inhibitors. By the construction of a graph, as described, the amount of activator which will cause the lysis of a $1.1 \mathrm{ml}$. standard clot containing excess plasminogen can be determined; this is defined as one standard clot unit of activator.

ANTI-ACTIVATOR ASSAY Inhibition of plasminogen activation may be brought about by two different mechanisms. Blood itself is able to exert an inhibitory effect on activators, which is probably equally potent against the intrinsic (plasma) activator and such artificial activators as streptokinase and urokinase. This inhibition by blood is not intrinsically present in the circulation, but is developed rapidly in shed blood, the rate of development probably being dependent upon surface contact, temperature, and the presence of platelets and calcium (Flute, 1960, 1962). The other form of inhibition against plasminogen activation to be found in whole blood is due to the presence of antibodies developed as a result of stimulation by heterologous protein antigens: the most important of these in humans is the anti-streptokinase antibody resulting from incidental streptococcal infections. The urokinase used so far has always been of human origin and anti-urokinase antibodies have not been reported in man, although human urokinase is probably antigenic to other species (Celander and Guest, 1960). The inhibitory effect of antibodies is not influenced by those factors governing the production of the blood anti-activator but is present in the circulating blood: by varying the conditions of collection of the blood sample it is therefore possible to assay the inhibitory effect of antibody alone or the total inhibition due to antibody plus blood inhibitor. Measurement of antibody activity is carried out on citrated, platelet-poor plasma collected and prepared with a meticulously observed cold technique, using plastic apparatus in order to prevent activation of the blood inhibitor. For the assay of total inhibition the test sample is collected and prepared under conditions which give maximum opportunity for activation of the inhibitor.

An important application of this method is to assess the inhibition which must be overcome before thrombolytic treatment with infusion of activator can become effective. Such inhibition is due to antibody against the activator being used; the demonstrable inhibitor in shed blood can be ignored because it is not active in the circulation. If urokinase is the activator of choice antibodies will not be present but when streptokinase is used, interference by antibodies is inevitable. Any assay must be carried out on cold-treated, non-activated, platelet-poor citrated or E.D.T.A. plasma, in order to calculate the initial dose of streptokinase which will neutralize the antibodies already present.

MEASUREMENT OF ANTI-STREPTOKINASE ANTIBODY CONCENTRATION Venous blood is collected with a plastic syringe which has been cooled to $4^{\circ} \mathrm{C}$. (the needle is not cooled). It is placed in a pre-cooled plastic tube containing $1 / 10$ volume of $3.8 \%$ trisodium citrate or $1 / 100$ volume of $10 \%$ E.D.T.A. and immediately centrifuged at 3,000 r.p.m. $(3,700 \mathrm{~g})$ for 10 minutes at $4^{\circ} \mathrm{C}$. The platelet-poor plasma is transferred to a second polystyrene tube in an ice-bath by means of a polystyrene Pasteur pipette, and the test set up immediately.

While the blood is being centrifuged, streptokinase of the type to be used for the treatment is standardized as described previously and a solution containing 10 
standard clot units per millilitre prepared. The test plasma is diluted 1 in 5 with saline phosphate buffer and further dilutions are made from this as shown in Table V, all tubes being kept in an ice-bath.

TABLE V

ANTI-ACTIVATOR ACTIVITY

\begin{tabular}{llll} 
Tube & Dilution & $\begin{array}{l}\text { Test Plasma or Serum } \\
\text { I } \text { in } 5(\mathrm{ml} .)\end{array}$ & $\begin{array}{l}\text { Saline Phosphate } \\
\text { Buffer }\end{array}$ \\
\hline 1 & $1: 1$ & 0.2 & - \\
2 & $1: 2$ & 0.1 & 0.1 \\
3 & $1: 4$ & 0.05 & 0.15 \\
4 & $1: 8$ & 0.02 & $0 \cdot 2$ \\
5 & $1: 16$ & 0.01 & 0.2 \\
6 & $1: 32$ & 0.01 of test 1 in 50 & 0.2 \\
7 & - & - & 0.2 \\
8 & - & - & 0.25 \\
9 & - & - & 0.25
\end{tabular}

To tubes 1-7 add $0.1 \mathrm{ml}$. streptokinase, 10 standard clot units per $\mathrm{ml}$.

To tubes 8 and 9 add $0.05 \mathrm{ml}$. streptokinase, 10 standard clot units per $\mathrm{ml}$.

All tubes are incubated in an ice-bath for 10 minutes to allow the inhibitor to act. At the end of this time the following components of the standard clot are added to each tube as rapidly as possible:

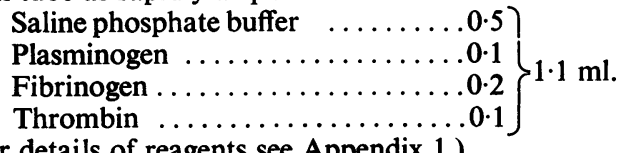

(For details of reagents see Appendix 1.)

A stop-watch is started as the thrombin is added and the tubes shaken and transferred immediately to a $37^{\circ} \mathrm{C}$. water-bath. They are examined at 30 -second intervals and the lysis times recorded. Tube no. 7 , containing 1 standard clot unit of streptokinase, should lyse in 10 minutes and is the streptokinase control.

MEASUREMENT OF TOTAL INHIBITION OF ACTIVATOR Venous blood is collected with a glass syringe and placed in a glass tube. The blood is allowed to clot at $37^{\circ} \mathrm{C}$. and incubated at this temperature for a further $\mathbf{2 0}$ minutes. Serum is obtained by centrifugation and is stored in a glass tube in an ice-bath until used.

The test is set up in the same way as for the assay of antibody activity. Inhibition against other extrinsic and artificial activators can be estimated by their inclusion in the test system instead of streptokinase.

INTERPRETATION OF RESULTS The lysis time of the clots in tubes 1-6 is plotted against the dilution of test plasma or serum on double logarithmic graph paper. By reference to this curve the dilution of test giving a lysis time corresponding to the lysis time given by the $\frac{1}{2}$ unit control (tubes 8 and 9) is found. This dilution multiplied by 5 (for original test dilution) gives the number of inhibition units per millilitre of the test, 1 unit of inhibition being defined as the amount which will inhibit $50 \%$ of the activator activity in a standard clot. From the result of the streptokinase antibody test and knowledge of the patient's plasma volume, the total amount of antibody present can be calculated and the initial dose of streptokinase prescribed accordingly (Johnson and McCarty, 1959).

PLASMIN ACTIVITY ASSAY The standard clot method is not used for estimating plasma plasmin activity because as for the estimation of endogenous activator, inhibitor $\bar{s}$ must be removed to unmask the fibrinolytic effect. It could be used to estimate fibrinolytic activity in patho logical fibrinolytic states where the inhibitor activity has been overcome, but other tests suitable for this are available. The principal value of the standard clot methodin this respect is in the assay and standardization of proprietary brands of plasmin: it should be noted tha? most of these are prepared by the addition of activator $-\frac{9}{8}$ usually streptokinase-to plasminogen and thereforeinevitably contain some free activator (Baumgarten et al. iv 1960). Unless a plasminogen-free assay system is used; the rate of lysis of the standard clot will be a measure of the fibrinolytic potential rather than a direct function of the plasmin added.

One standard clot unit of plasmin may be defined as the amount which will lyse a standard clot in 10 minutes Dilutions of the test material are made in saline-phosphates buffer to contain $500,100,50,40,30,20,10,1$, and $0 \cdot 1^{-}$ manufacturer's units. Each dilution is tested in the follow ing standard clot mixture.

Saline phosphate buffer $\ldots \ldots \ldots .6 \cdot 6$

(Plasminogen) ${ }^{1} \ldots \ldots \ldots \ldots \ldots \ldots .1$

Plasmin dilution $\ldots \ldots \ldots \ldots \ldots .0 .1\} 1 \cdot 1 \mathrm{ml}$.

Fibrinogen ...............

Thrombin $\ldots \ldots \ldots \ldots \ldots \ldots \ldots .1$

${ }^{1}$ Plasminogen is replaced by saline phosphate buffer if a plasminogen free system is being used for the assay of plasmin alone.

The lysis time given by each plasmin dilution is noted. Lysis times are plotted against dilution of test materia on double logarithmic graph paper. From the graph the dilution which will lyse a standard clot in 10 minutes is determined; this will contain one standard clot unit of fibrinolytic activity.

\section{APPENDIX I}

\section{BASIC MIXTURE FOR STANDARD CLOT TESTS}

Saline phosphate buffer + test substance $(\mathrm{s}) \ldots . .60 .6 \mathrm{ml} \frac{\mathrm{D}}{\mathrm{O}}$

Plasminogen (pre-standardized human serum

euglobulin ................... $\mathrm{ml}$

Fibrinogen (pre-standardization bovine

plasma fraction 1) ............... $\mathrm{ml}$.

Activator (10 standard clot units $/ \mathrm{ml}.) \ldots \ldots \ldots .1 \mathrm{ml}$.

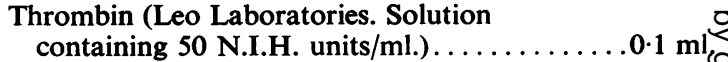

Total volume. . . . . . . . . . .

\section{APPENDIX 2}

METHODS USED FOR THE IDENTIFICATION OF CONTAMINANTS IN THE REAGENTS

1 PLASMIN Heated fibrin plates (Lassen, 1952).

2 PLASMINOGEN Heated fibrin plates. Test material mixed with an equal volume of streptokinase $(1,000,100$, 
and 10 units $/ \mathrm{ml}$.) and human serum $(1 / 100)$ or human activation product as a source of proactivator (Mullertz and Lassen, 1953; Hawkey, 1963).

3 PlASMINOGEN ACTIVATOR Unheated fibrin plates and plates prepared from a euglobulin precipitate of bovine plasma fraction $\mathbf{I}$. The euglobulin precipitate contains fibrinogen and plasminogen and plates prepared from it are more sensitive to minor degrees of plasmin activity than are standard unheated fibrin plates because the anti-plasmin level is reduced (Kowalski et al., 1959).

4 PROACTIVATOR Unheated fibrin plates. Test material mixed with an equal volume of streptokinase $(1,000$, 100 , and 10 units/ml.).

5 ANTI-ACTIVATOR Modified standard clot method as described in the text. When fibrinogen was the test material it was first clotted with thrombin and the fibrin clot removed with a wooden applicator stick, care being taken to squeeze out as much as possible of the liquid trapped in the clot. This was done in order that the presence of extra fibrinogen would not influence the final result of the test.

6 ANTI-PLASMINS Modification of the method described by Howell (1963) using a more dilute plasmin solution. Fibrinogen solutions were treated as for the measurement of anti-activators.

All fibrin plates were prepared from bovine plasma fraction I (Armour) and Thrombin Reagent (Leo). Tests were set up in triplicate and repeated at least twice. Appropriate controls were carried out in each case. Results obtained on fibrin plates were confirmed by the standard clot method.

\section{APPENDIX 3}

BUFFERS

Saline phosphate buffer has been used in the tests described in this paper. It removes ionic calcium which exerts an inhibitory effect on the fibrinolytic system.

SALINE-PHOSPHATE BUFFER

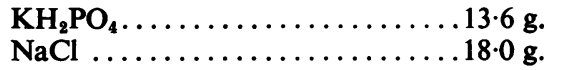

Merthiolate ............. $200 \mathrm{mg}$.

$5 \mathrm{~N} \mathrm{NaOH} \quad \ldots \ldots \ldots \ldots \ldots \ldots . \ldots 18 \mathrm{ml}$.

Make up to $2,000 \mathrm{ml}$. with distilled water. Adjust to $p H \mathbf{H}$ 7.5. This buffer is used to dissolve all reagents except the streptokinase.

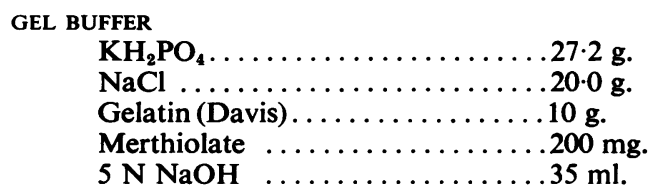

Make up to 2,000 ml. with distilled water. Adjust to $p \mathrm{H} \mathrm{7.5.} \mathrm{This} \mathrm{buffer} \mathrm{is} \mathrm{used} \mathrm{for} \mathrm{the} \mathrm{preparation} \mathrm{of} \mathrm{strepto-}$ kinase dilutions, and gelatin has been added because the provision of a gel serves to stabilize the streptokinase during the time taken to complete the procedure.

\section{APPENDIX 4}

PREPARATION OF HUMAN SERUM EUGLOBULIN AS A SOURCE OF PLASMINOGEN

Human serum euglobulin is prepared from time-expired bank blood in the following way. Citrated (A.C.D.) plasma from 10 donors is pooled; the plasma may have been stored at $-35^{\circ} \mathrm{C}$. if necessary. One thousand N.I.H. units of Leo thrombin reagent are added per $120 \mathrm{ml}$. plasma, and the plasma incubated at $37^{\circ} \mathrm{C}$. for 30 minutes to ensure complete conversion of fibrinogen to fibrin. The fibrin clot is removed and discarded, as much liquid as possible being squeezed out beforehand. One part of serum is added to 19 parts of glass-distilled water at $4^{\circ} \mathrm{C}$. and the $\mathrm{pH}$ adjusted to 5.3 by the addition of 0.2 parts of $1 \%$ acetic acid. The mixture is left at $4^{\circ} \mathrm{C}$. for 30 minutes to allow for complete precipitation of the euglobulins. The precipitate is obtained by centrifugation at 1,500 r.p.m. $(1,000 \mathrm{~g})$ for 15 minutes, and redissolved to one quarter of the original volume of serum in saline phosphate buffer. The euglobulin solution is stored in aliquots in plastic containers at $-35^{\circ} \mathrm{C}$. and must be standardized before use.

This work was made possible by grants from the Medical Research Council and the St. George's Hospital Research Fund. We are particularly indebted to Dr. Margaret Howell and Miss Sally Bruce, B.Sc., for their comments and advice.

The commercial preparations investigated were kindly donated by Kabi Pharmaceuticals, Leo Pharmaceuticals, Parke, Davis Ltd. and William R. Warner \& Co. Ltd.

\section{REFERENCES}

Astrup, T., and Mullertz, S. (1952). Arch. Biochem., 40, 346. Baumgarten, W., Ciminera, J. L., and Cole, R. B. (1960). Vox. Sang. (Basel), 4, 416.

Blix, S. (1962). Acta med. scand., 172, suppl., 386.

Bruce, S. (1964). J. clin. Path., 17. In press

Celander, D. R., and Guest, M. M. (1960). Amer. J. Cardiol., 6, 409

Christensen, L. R. (1949). J. clin. Invest., 28, 163.

Fletcher, A. P. (1954). Biochem. J., 56, 677.

Flute, P. T. (1960). Proc. 7th Congr. europ. Soc. Haemat., London, 1959. Part 2, p. 894.

- (1962). Personal communication.

Hawkey, C. (1963). Nature (Lond.), 197, 162.

Howell, M. B. (1963). J. clin. Path., 16, 289.

Innes, D. M. (1962). Personal communication.

Johnson, A. J., and McCarty, W. R. (1959). J. clin. Invest., 38, 1627. , and Tillett, W. S. (1952). J. exp. Med., 95, 449.

Kowalski, E., Kopec, M., and Niewiarowski, S. (1959). J. clin. Path., $12,215$.

Lassen, M. (1952). Acta physiol. scand., 27, 371.

McNicol. G. P. (1962). Personal communication.

Mosesson, M. W. (1962). Biochim. biophys. Acta. (Amst.), 57, 204.

Mullertz, S., and Lassen, M. (1953). Proc. Soc. exp. Biol. (N.Y.), 82, 264. 